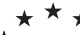

$\star$ Polltyki Europejskie.

$\star$ Finanse i Marketing

$\star \star \star \quad 17$ (66) 2017

Anna Augustyn

Uniwersytet w Bialymstoku

Marta Hereźniak

Uniwersytet Lódzki

Magdalena Florek

Uniwersytet Ekonomiczny w Poznaniu

\title{
W poszukiwaniu wiarygodnych metod pomiaru skuteczności budowania marek miast ${ }^{1}$
}

\section{IN SEARCH OF RELIABLE METHODS OF ASSESSING THE EFFECTIVENESS OF PLACE BRANDING ACTIVITIES UNDERTAKEN BY CITIES}

Celem artykułu jest przedstawienie różnorodnych perspektyw rozumienia skuteczności działań na rzecz budowania marek miast. Autorki proponuja podejście do zagadnienia pomiaru skuteczności strategii marki miasta, czerpiqc zarówno z dorobku marketingu, jak i zarzqdzania publicznego oraz określaja implikacje takiego podejścia dla praktyki zarzadzania markami miast.

$W$ opracowaniu zastosowano analize aktualnych podejść do pomiaru skuteczności działań marketingowych przez miasta, uwzględniajac perspektywę marketingowa i zarzadzania publicznego. Analiza dotyczyła przegladu zatożeń powyższych ujęć w kontekście stosowanych metod pomiaru. Szczególnq uwage poświęcono koncepcji kapitału marki terytorialnej, który jest propozycja kompleksowego ujęcia skuteczności podejścia marketingowego wyrażonego $w$ kategoriach marki, uwzględniajacego przede wszystkim perspektywę nabywców oferty jednostek samorzadowych.

Projektując system pomiaru skuteczności strategii marki miasta, podmioty publiczne powinny rozpoczqć od ustalenia czym jest marka miejsca, jakie funkcje petni i jaki jest potencjalny zakres jej oddziaływania. Nastęnie przyjmujac wskaźniki oceny skuteczności powinny równolegle uwzględnić te, które będq odnosity się do kilku wybranych metod pomiarowych, uwzględniajacych materialne i niematerialne (wizerunkowe, emocjonalne) rezultaty, wywodzace się nie tylko $z$ marketingu, ale również z zarzqdzania publicznego oraz biorqc pod uwage różne perspektywy czasowe występowania owych rezultatów. Pozwoli to na bardziej całościowe ujęcie oddziaływania marki na rzeczywistość jednostki terytorialnej, jaka jest miasto.

Słowa kluczowe: marketing terytorialny, branding, metody pomiaru skuteczności marek miast, kapitał marki

\footnotetext{
1 Artykuł powstał na bazie I etapu badań prowadzonych w ramach projektu badawczego nr 2015/19/B/HS4/00380 pt. „Możliwości pomiaru skuteczności strategii marek polskich miast (na przykładzie polskich miast powiatowych) - ujęcie teoretyczne i empiryczne".
} 


\section{Wstęp}

W ostatnich latach zaobserwować można dynamiczny wzrost znaczenia podejścia marketingowego w zarządzaniu miastami. Marketing terytorialny stał się przedmiotem zainteresowań środowisk akademickich oraz samorządów, które upatrują w nim sposób na bardziej skuteczne i efektywne rezultaty prowadzonych polityk, wdrażanych strategii i działań. Zarówno jednak włodarze czy pracownicy samorządowi, jak i badacze przedmiotu, artykułują potrzebę systematycznego ujęcia tej koncepcji oraz pomiaru jej efektów w kontekście celów ogólnych i długookresowych miast, którym podejście marketingowe ma służyć. $Z$ jednej strony bowiem akademicy wskazują potrzebę stworzenia silnych podstaw teoretycznych dziedziny jaką jest marketing miejsc i związana z nim marka terytorialna, z drugiej, oczekiwania społeczne co do skuteczności zarządzania miastami, które towarzyszą zmieniającym się uwarunkowaniom tego procesu, wymagają jednoznacznej ewaluacji.

Celem artykułu jest przedstawienie różnych perspektyw rozumienia skuteczności podejścia marketingowego w miastach, które wyznaczają kierunek dalszych rozstrzygnięć W zakresie operacjonalizacji pomiaru skuteczności działań marketingowych. W opracowaniu przedstawiono zarówno ujęcie marketingowe oraz perspektywę zarządzania publicznego. Szczególną uwagę poświęcono kapitałowi marki terytorialnej, który jest propozycją kompleksowego ujęcia skuteczności podejścia marketingowego wyrażonego w kategoriach marki, uwzględniającego przede wszystkim perspektywę nabywców oferty jednostek samorządowych.

\section{Skuteczność w marketingu}

Pomiar skuteczności jest jednym $\mathrm{z}$ najbardziej złożonych zadań w marketingu, jednocześnie skuteczność pełni wiele kluczowych funkcji - przyczynia się do polepszenia procesu podejmowania decyzji marketingowych, redukuje ryzyko dzięki lepszemu zrozumieniu odbiorców, umożliwia ulepszenie działań marketingowych w przyszłości oraz prowadzi do oszczędności kosztów i kumulacji wiedzy, lepszej alokacji zasobów, a przede wszystkim weryfikacji celów marketingowych danego podmiotu.

Skuteczność to pozytywnie oceniana zgodność wyniku z celem². Zdaniem J. Zieleniewskiego, działanie jest skuteczne wówczas, gdy osiaga zamierzony cel, umożliwia lub ułatwia jego osiągnięcie. Przy ocenie skuteczności nie bierze się pod uwagę kosztu, a spośród wyników - tylko te przewidywane ${ }^{3}$. Mierząc stosunek osiagniętego celu (efektu) do zaplanowanego, można określić skuteczność procentowo. Skuteczność jest przy tym jednym z aspektów efektywności. Odnosi się bowiem do uzyskiwania efektów działań. Działanie może być bowiem efektywne, choć nieskuteczne, wtedy, gdy cele zostały zaplanowane na zbyt wysokim, niemożliwym do osiagnięcia poziomie ${ }^{4}$.

Oznacza to, że skuteczności nie należy utożsamiać z efektywnością i tym bardziej używać tych pojęć zamiennie. Efektywność bowiem to zależności pomiędzy

\footnotetext{
2 J. Pszczołowski: Mała encyklopedia prakseologii i teorii organizacji. Ossolineum, Wrocław 1978, s. 219.

${ }^{3}$ J. Zieleniewki: Organizacja i Zarzqdzanie. PWN, Warszawa 1976, s. 225.

${ }^{4}$ H. Szulce, T. Żyminkowski: Znaczenie efektywności działań marketingowych $w$ ksztaltowaniu wartości przedsiębiorstwa. Wyd. Uniwersytetu Ekonomicznego w Poznaniu, Poznań 2010, s. 25.
} 
finansowymi efektami i nakładami na działalność marketingową. Działanie jest efektywne, jeśli w rzeczywistości przyniosło nadwyżkę mierzalnych efektów nad kosztami ${ }^{5}$.

Z punktu widzenia działań marketingowych skuteczność oznacza zatem stopień osiągnięcia celów założonych w planie/strategii marketingowej. Efektywność z kolei odnosi się do relacji efektów uzyskanych wskutek działań marketingowych do nakładów poniesionych na ich uzyskanie. Warto jednak zaznaczyć, iż w przypadku działań marketingowych relacja efekty-nakłady bardzo często ma wymiar niefinansowy (niepieniężny) ${ }^{6}$.

Skuteczność marketingu można traktować jako kryterium oceny, w jakim stopniu dane działanie rzeczywiście doprowadziło do osiagnnięcia zaplanowanego celu. Stąd skuteczność wiąże się z systemem sformułowanych celów strategicznych i operacyjnych ${ }^{7}$. Dlatego też w planie/strategii marketingowej należy skupić szczególnie dużą uwagę na tym, aby zapisane cele jasno określały przyszły, pożądany stan rzeczy lub procesu. Koncepcję prawidłowego definiowania celów komunikacji marketingowej prezentuje formuła SMARRTT ${ }^{8}$, zgodnie z którą cele powinny być: ${ }^{9}$

- Specified (jasne) - jasne, precyzyjne oraz ukierunkowane na to, co konkretnie ma być osiągnięte (np. budowanie świadomości marki, zmiana postaw itp.),

- Measurable (mierzalne) - mierzalne, tak aby po zakończeniu działań można było określić stopien ich realizacji,

- Achievable (osiaggalne) - ustalone $\mathrm{w}$ taki sposób, aby mogły być osiagnnięte $\mathrm{w}$ ramach środków, które ma się do dyspozycji,

- Realistic (realistyczne) - realistyczne (np. duży wzrost świadomości marki w krótkim okresie czasu nie jest realistyczny),

- Relevant (odpowiednie) - dostosowane do problemów. W sytuacji, kiedy określony problem zostanie zidentyfikowany, konkretne cele szczegółowe powinny dotyczyć tego problemu,

- Targeted (odniesione do segmentów) - sformułowane w odniesieniu do adresatów, z którymi chce się skomunikować. Jeśli jest wielu odbiorców komunikacji, w odniesieniu do każdej z grup powinno się cele,

- Timed (określone w czasie) - określone w czasie, aby wskazać, kiedy mają być realizowane. Dzięki temu możliwe jest monitorowanie działań oraz wskazanie, kiedy można dokonać ich oceny.

Każdemu etapowi realizacji działań marketingowych powinna towarzyszyć analiza ich skuteczności. Zaniechanie zdefiniowania celów i ustalenia wskaźników dokonań powoduje brak możliwości ustalenia, czy osiagnięto zamierzony cel. Dlatego też rezultaty osiagania założonych celów powinny być przedmiotem kontroli, której funkcja sprowadza się do wychwytywania nieprawidłowości i odchyleń podczas realizacji

\footnotetext{
${ }^{5}$ A. Łapiński: Badania mediów dla celów reklamy, [w:] Komunikacja marketingowa, Rydel M. (red.). Ośrodek Doradztwa i Doskonalenia Kadr, Gdańsk 2001, s.349.

${ }^{6}$ M. Malinowska: Efektywność i skuteczność komunikacji marketingowej. Difin, Warszawa 2015, s. 22.

${ }^{7}$ H. Szulce, T. Żyminkowski: Znaczenie efektywności działań marketingowych w kształtowaniu wartości przedsiębiorstwa. Wyd. Uniwersytetu Ekonomicznego w Poznaniu, Poznań 2010, s. 26.

${ }^{8}$ Formuła SMARRTT jest rozwinięciem pierwotnej koncepcji definiowania celów tj. SMART (ang. Specific, Measurable, Achievable, Realistic, Time-bound).

${ }^{9}$ M. Malinowska: Efektywność i skuteczność komunikacji marketingowej. Difin, Warszawa 2015, s. 23.
} 
planu/strategii, a także do oceny zgodności rezultatów działania z wytyczonymi celami i stopniem ich realizacji. Służy temu między innymi monitorowanie i ewaluacja.

W literaturze przedmiotu często pojawia się krytyka badań nad skutecznością (i efektywnościa) działań marketingowych. Związana jest ona głównie z krótkookresową perspektywą nadmierną liczbą różnego typu miar i wynikającą z tego trudnością ich porównywania, uzależnieniem analizowanych wyników od zestawu wybranych wskaźników oraz nie przywiazzywaniem uwagi do kreowania wartości dla udziałowców ${ }^{10}$.

W roku 2004 R.T. Rust, T. Ambler, G.S. Carpenter, V. Kumar i R.K. Srivastava przedstawili model skuteczności działań marketingowych skonstruowany w oparciu o zależności między działaniami (i wydatkami) marketingowymi a wzrostem wartości, wskazując na to, iż celem działań marketingowych jest tworzenie wartości dla udziałowców. W modelu tym pierwsze założenie jest takie, iż kluczowym problemem badawczym w marketingu jest skuteczność działań marketingowych rozumiana jako ich zdolność do przyczyniania się do wzrostu wartości przedsiębiorstwa/podmiotu prowadzącego działania marketingowe. Ponadto skuteczność działań marketingowych powinna być badana jako wpływ, przez efekty pośrednie (aktywa marketingowe, pozycja rynkowa), na wielkości finansowe i ostatecznie na wartość rynkową jednostki. Autorzy modelu zwracają uwage, że zakres badań $\mathrm{w}$ marketingu powinien zostać poszerzony o badania wpływu działań marketingowych na wartość ${ }^{11}$. Według autorów, skuteczne działania marketingowe to takie, które wpływają na aktywa marketingowe jednostki, tj. na: kapitał marki (ang. brand equity) i kapitał klientów (ang. customer equity) $)^{12}$.

W niniejszym artykule uwaga zostanie skupiona na analizie kapitału marki, jako możliwego podejścia do oceny rezultatów marketingowych miast.

\section{Pomiar skuteczności strategii marketingowych miast z perspektywy marketingu i zarządzania publicznego}

\section{Skuteczność i efektywność w sektorze publicznym}

Skuteczność i efektywność działań instytucji publicznych są narzucone przepisami ustawy o finansach publicznych z 2009 roku, w której zobowiązuje się podmioty do „wydatkowania środków publicznych z zachowaniem zasad uzyskiwania najlepszych efektów z danych nakładów oraz optymalnego doboru metod i środków służących osiągnięciu założonych celów"13. Na fali zmian w paradygmacie zarządzania publicznego, wraz z pojawieniem się koncepcji Nowego Zarządzania Publicznego (ang. New Public Management) i nadzoru (ang. governance), do sektora publicznego wprowadzono obowiązek wprowadzenia kontroli zarządczej, której jednym z najistotniejszych celów jest właśnie działanie zgodnie z zasadami skuteczności i efektywności.

\footnotetext{
${ }^{10}$ H. Szulce, T. Żyminkowski: Znaczenie efektywności dziatań marketingowych $w$ ksztaltowaniu wartości przedsiębiorstwa. Wyd. Uniwersytetu Ekonomicznego w Poznaniu, Poznań 2010, s. 32.

${ }^{11}$ R. Kłeczek: Marketing i wartość. Metodologiczne aspekty badania skuteczności i dziatań marketingowych. Uniwersytet Ekonomiczny we Wrocławiu, Wrocław 2012, ss. 19-22.

${ }^{12}$ Ibidem, s. 19.

${ }^{13}$ Ustawa o finansach publicznych z dnia 27 sierpnia 2009, Dz.U. 2009 Nr 157 poz. 1240, art. 44 pkt. 3.
} 
Według R. Matwiejczuka ${ }^{14}$, efektywność należy definiować jako poszukiwanie oszczędności przy jednoczesnym dążeniu do maksymalizacji efektów działań i to właśnie na ten ostatni element kładzie się szczególny nacisk. W sferze publicznej, przyjęcie takiego założenia $\mathrm{w}$ odniesieniu do wszystkich obszarów działalności publicznej jest w zasadzie niemożliwe, zatem, jak pisze O. Szołno „efektywność polega na osiaganiu wyznaczonych celów z zachowaniem najlepszego stosunku ponoszonych kosztów do uzyskiwanych rezultatów"15.

Skuteczność $\mathrm{w}$ instytucjach publicznych nie jest i nie powinna być mierzona $\mathrm{w}$ sposób wyłącznie w sposób dosłowny, np. liczba oddanych do użytku przedszkoli lub dróg. Ważniejszą miarą skuteczności jest stopień zaspokojenia potrzeb społecznych, takich jak np. zwiększenie komfortu mieszkańców w wyniku poprawy jakości dróg czy usytuowania przedszkoli w kluczowych lokalizacjach ${ }^{16}$.

Pomiar skuteczności i efektywności jest częścią procesu zarządzania wynikami (ang. performance management), który składa się z czterech etapów: planowanie, realizacja, monitoring, ocena ${ }^{17}$. Zarządzanie wynikami pełni różnorodne funkcje $\mathrm{w}$ zarządzaniu publicznym. J. Lin i P. L, wyróżniają siedem sposobów rozumienia „wyników” w sektorze publicznym (por. tab. 1.). Obrazują one również funkcje, jakie zarządzanie wynikami pełni w funkcjonowaniu podmiotów publicznych. Są ponadto dowodem na to, że takie pojęcia jak wyniki, skuteczność, efektywność mają znacznie bardziej złożone znaczenie w sektorze publicznym niż w sferze prywatnej/nastawionej na zysk.

Tabela 1. Interpretacje pojęcia „wyniki” (performance) w sektorze publicznym

\begin{tabular}{|c|c|}
\hline Interpretacja & Istota \\
\hline - Wyniki jako odpowiedzialność & $\begin{array}{l}\text { Wyniki są dowodem na dążenie instytucji publicznej do poprawy, } \\
\text { co czyni ją odpowiedzialną w oczach interesariuszy. }\end{array}$ \\
\hline - Wyniki jako wybór użytkownika & $\begin{array}{l}\text { Informacje o wynikach mogą być istotnym czynnikiem } \\
\text { decydującym o wyborze danej jednostki publicznej np. do } \\
\text { współpracy w ramach różnych projektów (np. inwestor wybiera } \\
\text { lokalizację z uwagi na postrzeganą efektywność i skuteczność } \\
\text { administracji publicznej). }\end{array}$ \\
\hline - Wyniki jako obsługa klienta & $\begin{array}{l}\text { Wynika z przeświadczenia, że ludzie i organizacje powinni być } \\
\text { traktowani jako klienci instytucji publicznych, stąd konieczne są } \\
\text { dobre wyniki w zakresie poziomu świadczonych usług. }\end{array}$ \\
\hline - Wyniki jako efektywność & Wyniki jako optymalna zależność między nakładami a rezultatami. \\
\hline $\begin{array}{l}\text { Wyniki jako skuteczność, } \\
\text { rozwiązanie, które działa }\end{array}$ & $\begin{array}{l}\text { Wyniki jako realne problemy, które udało się rozwiązać w wyniku } \\
\text { podjętych działań, często niezależnie od wielkości wydatkowanych } \\
\text { środków. }\end{array}$ \\
\hline - Wyniki jako alokacja zasobów & $\begin{array}{l}\text { Informacje o wynikach są kluczową informacją niezbędną do } \\
\text { alokacji zasobów. }\end{array}$ \\
\hline - Wyniki jako wartość publiczna & $\begin{array}{l}\text { Wyniki nie jako „generyczny produkt” budżetu, ale jako } \\
\text { świadectwo wytworzonej wartości publicznej. }\end{array}$ \\
\hline
\end{tabular}

\footnotetext{
${ }^{14}$ R. Matwiejczuk: Zarzqdzanie marketingowo-logistyczne. Wartość i efektywność. C.H. Beck, Warszawa 2006.

${ }^{15}$ O. Szołno: Wybrane aspekty pomiaru efektywności i skuteczności jednostki samorzqdu terytorialnego. Finanse, Rynki Finansowe, Ubezpieczenia, 6/1 (84), 91-99. DOI: 10.18276/frfu.2016.84/1-08, 2016. s. 92.

${ }_{16}$ P. Modzelewski: Kontrola zarzadcza $w$ jednostkach sektora publicznego $w$ zakresie pomiaru skuteczności $i$ efektywności, [w:] Sienkiewicz P., Świeboda H. (red.): Bezpieczeństwo, efektywność, budżet zadaniowy. AON, Warszawa 2014.

${ }^{17}$ J. Lin, P. Lee: Performance Management in Public Organizations: A Complexity Perspective. International Public Management Review, Vol. 12, No. 2, 2011, s. 87.
} 
Źródło: opracowanie własne na podstawie: J. Lin, P. Lee: Performance Management in Public Organizations: A Complexity Perspective. International Public Management Review, Vol. 12, No. 2, 2011, s. 87.

Mając na względzie powyższe interpretacje, należy stwierdzić, że zarządzanie wynikami w sektorze publicznym trzeba traktować szerzej niż tylko kontrolę nad wydawanymi środkami publicznymi. B. Sun proponuje, aby proces ten postrzegać jako: ${ }^{18}$

- program kontroli: nadzorowanie i monitorowanie podejmowanych działań w celu eliminacji błędów i słabych ogniw;

- $\quad$ komunikację polityczną: jest to sposób demokratycznie wybranych władz na zwiększenie politycznej kontroli nad instytucjami publicznymi w celu zwiększania jakości usług publicznych. Użytkownicy usług publicznych mogą wykorzystywać wskaźniki i wyniki osiagane przez instytucje do oceny zdolności politycznych i zarządczych władz;

- funkcję przywództwa: współcześnie panuje przeświadczenie, że władze publiczne powinny pełnić funkcję ,nawigatora”, który wprowadza do sfery publicznej kulturę zorientowaną na rezultaty i potrzeby klienta (w miejsce sztywnej hierarchii i odgórnego zarządzania).

Istotną rolę $\mathrm{w}$ ewolucji podejścia do pomiaru skuteczności i efektywności w sektorze publicznym odegrał wspomniany już paradygmat nowego zarządzania publicznego, wywodzący się z krajów anglosaskich. W myśl jego istoty, sektor publiczny, aby działać skutecznie i efektywnie, winien adaptować techniki pomiaru stosowane w sektorze prywatnych przedsiębiorstw. M. Arnaboldi i in. ${ }^{19}$ identyfikują trzy metody, które zostały przeniesione $\mathrm{z}$ sektora firm do organizacji publicznych: Benchmarking i zastosowanie kluczowych wskaźników efektywności (ang. Key Performance Indicators, KPI), Zrównoważona Karta Wyników oraz Lean Management. Obok tradycyjnej kontroli budżetowej i kierowniczych list kontrolnych stanowią one katalog sposobów pomiaru efektywności i skuteczności. Z sektora prywatnego coraz częściej na grunt publiczny przenosi się także koncepcję marki i sposoby jej pomiaru jako indykatora poziomu skuteczności marketingu w miastach..

\section{Koncepcje pomiaru skuteczności marki terytorialnej}

Analizując literaturę z zakresu budowania marek terytorialnych, należy stwierdzić, że panuje w niej zasadnicza zgodność co do konieczności wypracowania przez jednostki samorządu terytorialnego bardziej systemowego i holistycznego podejścia do skutecznego jej zarządzania $^{20}$. Potrzeba zastosowania podejścia systemowego staje się szczególnie ważna w przypadku kluczowych etapów zarządzania marką: jej

\footnotetext{
${ }^{18}$ B. Sun: Public Management. Bestbooks Publisher New, Taipei 2009.

19 M. Arnaboldi, I. Lapsley, I. Steccolini: Performance Management in the Public Sector: The Ultimate Challenge. Financial Accountability \& Management, 31(1), February,0267-4424, 2015, s.7 i nast.

${ }^{20}$ S. Anholt: Competitive Identity: The New Brand Management for Nations, Cities and Regions. Palgrave Macmillan, New York 2007; S. Hanna, J. Rowley: Towards a strategic place brand-management model. Journal of Marketing Management, Vol. 27 Nos 5/6, 2011; M. Hereźniak: Marka Narodowa. Jak skutecznie budować wizerunek i reputację kraju. PWE, Warszawa 2011.
} 
wprowadzania $\mathrm{i}$ ewaluacji ${ }^{21}$. Mimo to, pomiar skuteczności tej sfery marketingu terytorialnego pozostaje niedostatecznie przeanalizowany $\mathrm{w}$ literaturze przedmiotu ${ }^{22}$. Analiza zagadnienia pomiaru skuteczności marki $\mathrm{z}$ perspektywy zarządzania publicznego wskazuje na kluczową rolę takich czynników jak: nieustanna analiza rynku, współpraca wewnątrz instytucjonalna i międzyinstytucjonalna, a także kooperacja prywatno-publiczna $\mathrm{w}$ skutecznym wdrażaniu polityk publicznych mających na celu przyciaganie zewnętrznych „użytkowników”, takich jak inwestorzy czy turyści ${ }^{23}$. Ponadto w wyniku ewolucji sektora publicznego w kierunku proefektywnościowym, w koncepcjach z zarządzania publicznego wykształciły się narzędzia pomiaru skuteczności i efektywności, wiedza o sposobie tworzenia wskaźników skuteczności i inne koncepcje $^{24}$, które mogą być adaptowane na potrzeby budowania marki miasta.

Jedną z najważniejszych koncepcji jest tzw. podejście logiczne (ang. logic framework), opisujące sposób tworzenia wskaźników skuteczności w sektorze publicznym. Uwzględnia ono różne perspektywy czasowe efektów strategii marki i różne grupy interesariuszy ${ }^{25}$. Koncepcja ta została podsumowana na rysunku 1.

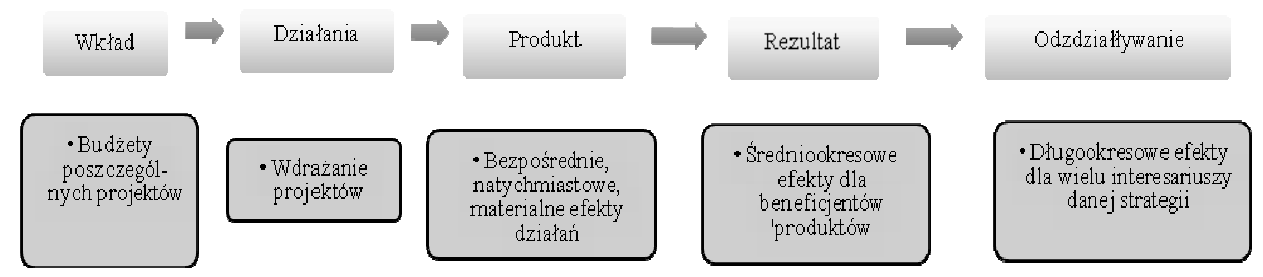

Rysunek 1. Podejście logiczne do tworzenia wskaźników skuteczności w sektorze publicznym Żródło: G. Bouckaert, J. Halligan: Managing performance, International comparisons. Routledge, London 2008.

W odniesieniu do przedstawionego modelu, $\mathrm{w}$ tabeli 2 dokonano zestawienia przykładowych wskaźników skuteczności marki terytorialnej w podziale na wskaźniki produktu, rezultatu i oddziaływania. Należy przy tym podkreślić, że treść wskaźników jest każdorazowo uzależniona od przyjętej strategii marki - będą one zatem silnie skontekstualizowane. W tabeli 3 ujęto generyczne wskaźniki, które mogą się pojawić bez względu na zawartość dokumentów strategicznych JST.

${ }^{21}$ S. Hanna, J. Rowley: Towards a strategic place brand-management model. Journal of Marketing Management, Vol. 27 Nos 5/6, 2011.

${ }^{22}$ S. Pike: Consumer brand equity measures. Journal of Travel and Tourism Marketing, 22(1), 2007; M. Florek: Kapital marki miasta zorientowany na konsumenta - źródła i pomiar. Wydawnictwo Uniwersytetu Ekonomicznego w Poznaniu, Poznań 2014.

${ }_{23}$ J. Anders-Morawska, W. Rudolf: Orientacja rynkowa we wspótrzqdzeniu miastem. Wydawnictwo Uniwersytetu Łódzkiego, Łódź 2015.

${ }^{24}$ S. Russo, F. Frnetii, J. Guthrie, G. Marcon: Public Value Management: Measuring and Reporting. Emerald Group Publishing, Bingley 2014.

${ }^{25}$ G. Bouckaert, J. Halligan: Managing performance, International comparisons. Routledge, London 2008. 
Tabela 2. Przykładowe wskaźniki produktu, rezultatu i odziaływania z perspektywy marki terytorialnej

\begin{tabular}{|c|c|c|}
\hline Wskaźniki produktu & Wskaźniki rezultatu & Wskaźniki oddziaływania \\
\hline $\begin{array}{l}\text { - Utworzenie organizacji ds. } \\
\text { zarządzania marką terytorialną } \\
\text { - Liczba zrealizowanych } \\
\text { kampanii promocyjnych miasta } \\
\text { - Produkty turystyczne powstałe } \\
\text { w wyniku wdrażania strategii } \\
\text { marki miejsca } \\
\text { - Pakiet udogodnień i korzyści } \\
\text { dla inwestorów zagranicznych } \\
\text { wypracowany przez władze } \\
\text { miasta } \\
\text { - Liczba zorganizowanych } \\
\text { imprez związanych z marką } \\
\text { miasta } \\
\text { - Liczba wyprodukowanych } \\
\text { materiałów promocyjnych } \\
\text { - Liczba nowopowstałych } \\
\text { punktów informacji } \\
\text { turystycznej } \\
\text { - Wyodrębnienie w ramach } \\
\text { administracji, jednostki } \\
\text { zajmującej się koordynacją } \\
\text { działań związanych z marką }\end{array}$ & 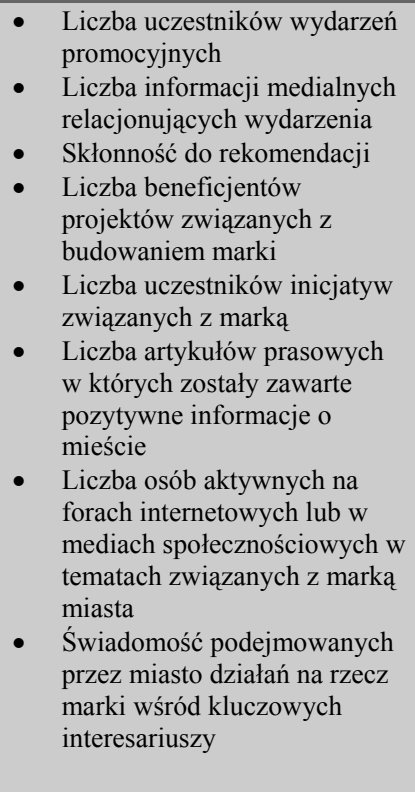 & $\begin{array}{l}\text { - Lojalność/skłonność do } \\
\text { ponownego przyjazdu/ } \\
\text { uczestnictwa } \\
\text { - } \\
\text { Spontaniczna i wspomagana } \\
\text { świadomość marki } \\
\text { - } \quad \text { ekwiwalent reklamowy } \\
\text { - } \quad \text { skłonność do rekomendacji } \\
\text { znajomość skojarzeń, } \\
\text { atrybutów, osobowości marki } \\
\text { - } \quad \text { Ocena akcji promujących miasto } \\
\text { - Ocena usług organizacji } \\
\text { odpowiadających za turystykę, } \\
\text { inwestycje, promocję } \\
\text { Ocena działań i wizerunek } \\
\text { władz miasta wewnątrz i na } \\
\text { zewnatrz } \\
\text { Rozdźwięk między tożsamością } \\
\text { a wizerunkiem miasta } \\
\text { Poziom akceptacji mieszkańców } \\
\text { dla działań władz miejskich } \\
\text { Poziom 'lokalnego } \\
\text { patriotyzmu’, dumy z } \\
\text { przynależności do społeczności } \\
\text { lokalnej }\end{array}$ \\
\hline
\end{tabular}

Źródło: opracowanie własne.

Warto również podkreślić, że $\mathrm{w}$ dyscyplinie $\mathrm{z}$ zarządzania publicznego przyjmuje się, że sposób pomiaru skuteczności działań wpływa na stopień osiagania celów organizacji, co nazwane jest oddziaływaniem funkcjonalnym (ang. functional impact). Jest to ważna konstatacja z perspektywy pomiaru skuteczności strategii marek miast, bowiem oddziaływanie funkcjonalne jest uznawane za jeden $\mathrm{z}$ trzech fundamentów zdrowego systemu pomiarowego. Pozostałe dwa to: (1) obiektywne traktowania danych oraz (2) legitymizacja, co oznacza, że przyjęte wskaźniki są akceptowane przez tych, których dotyczą ${ }^{26}$.

W literaturze z zakresu marketingu terytorialnego przyjmuje się także rozróżnienie na metody pomiaru skuteczności zorientowane na klienta oraz zorientowane na markę: ${ }^{27}$

- Metody pomiaru zorientowane na klienta: bazują na wiedzy $\mathrm{z}$ dziedziny zarządzania marką i zachowań konsumenckich, proponując między innymi adaptację na sferę zarządzania JST takich koncepcji teoretycznych jak kapitał konsumenta $^{28}$ i satysfakcja klienta ${ }^{29}$;

26 G. Bouckaert: Conference paper, SSPA-SDA Bocconi Conference 2010, session: Public Sector Performance; managing Governments by numbers, http://sna.gov.it/www.sspa.it/wpcontent/uploads/2010/11/Bouckaert_Rome-2010.pdf, [data dostępu: 13.03.2017].

${ }^{27}$ S. Zenker: How to catch a city? , The concept and measurement of place brands. "Journal of Place Management and Development", vol. 4, 1, 2011, ss. 40-52.

${ }^{28}$ R. T. Rust, K. N. Lemon, V.A. Zeithaml: Return on marketing: Using customer equity to focus marketing strategy. Journal of Marketing, 2004, ss. 109-127. 
- Metody pomiaru zorientowane na markę: odnoszą się do pojęcia kapitatu marki $i^{30}$ jako siły napędowej wartości marki i możliwości jego wykorzystania w marketingu terytorialnym. Pojęcie to zostało szczegółowo omówione w kolejnej części opracowania.

Innym ważnym kryterium różnicującym podejście do pomiaru skuteczności działań związanych z budowaniem marki, jest sposób rozumienia (interpretacji) pojęcia marki terytorialnej przez przedstawicieli władz publicznych. Pomiar skuteczności marki terytorialnej, rozumianej z perspektywy promocyjnej, ogranicza się jedynie do pomiaru skuteczności komunikacji marketingowej, jeżeli natomiast marka JST będzie postrzegana z perspektywy polityki publicznej, zakres wskaźników skuteczności będzie o wiele większy i obejmie także np. elementy kultury organizacyjnej, zaangażowania społeczności lokalnej etc.

\section{Skuteczność z perspektywy kapitału marki - stosowane modele i metody pomiaru}

Jedną z możliwości ujęcia i analizy skuteczności działań marketingowych jest zastosowanie podejścia, w którym punktem odniesienia jest kapitał marki.

Według H.B. Kim i in. ${ }^{31}$ zazwyczaj pod uwagę brane są dwie perspektywy kapitału marki: wartość marki dla przedsiębiorstwa (z perspektywy finansowej) i wartość marki dla konsumenta (w kontekście podejmowania decyzji). Pierwszy aspekt koncentruje się na wynikach/rezultatach kapitału marki, takich jak: cena, udział w rynku, zysk, przyszłe przepływy finansowe, podczas gdy tzw. kapitał marki zorientowany na konsumenta (ang. customer-based brand equity) ${ }^{32}$ stawia w centrum skojarzenia i postawy odbiorców.

Koncepcja kapitału marki zyskała na uwadze w latach 80. Jej popularyzatorami akademickimi w latach 90. byli D.A. Aaker, R.K. Srivastava i A.D. Shocker, J.N. Kapferer oraz K.L. Keller.

Choć w literaturze przedmiotu odnaleźć można wiele koncepcji i dyskusji na temat definicji kapitału marki i jej pomiaru, to panuje zgoda co do tego, iż kapitał marki wiąże się z wartością dodaną nadawaną przez skojarzenia konsumentów z nazwą marki $\mathrm{i}^{33}$ oraz swego rodzaju użytecznością, którą konsumenci marki porównują $\mathrm{z}$ markami konkurencyjnymi ${ }^{34}$.

\footnotetext{
${ }^{29}$ A. Insch: Managing Residents' satisfaction with city life: application of importance satisfaction analysis. Journal of Town and City Management, 1(2), 2010, ss. 164-17.

${ }^{30}$ np. K.L. Keller: Conceptualizing, Measuring and Managing Customer-based Brand Equity. Journal of Marketing, vol. 57, no. 1, 1993; D.A. Aaker: Managing Brand Equity. Capitalizing on the Value of a Brand Name. The Free Press, New York 991.

${ }^{31}$ H.B. Kim, W.G. Kim, J.A. An: The Effect of Consumer-based Brand Equity on Firms' Financial Performance. Journal of Consumer Marketing, vol. 20, no. 4, 2003, s. 335-351.

32 K.L. Keller: Conceptualizing, Measuring and Managing Customer-based Brand Equity. Journal of Marketing, vol. 57, no. 1, 1993, ss. 1-22.

${ }^{33}$ L.C. Winters: Brand Equity Measures: Some Recent Advances. Marketing Research, vol. 3, 1991, s. 70-73; A. Chaudhuri: Brand Equity or Double Jeopardy?. Journal of Product \& Brand Management, vol. 4, no. 1, 1995, s. 26-32.

${ }^{34}$ S. Boo, J. Busser, S. Baloglu: A Model of Customer-based Brand Equity and Its Application to Multiple Destinations. Tourism Management, vol. 30, 2009, s. 219-231.
} 
The Marketing Science Institute zdefiniował kapitał marki jako „zbiór skojarzeń i zachowań po stronie konsumentów związanych z marką, właścicielem marki i pozostałymi podmiotami zaangażowanymi z markę, które pozwalają marce generować większą niż przeciętna wielkość sprzedaży lub wyższą marżę". Podobnie uważa D.A. Aaker $^{35}$, według którego „kapitał marki ma charakter strategiczny - to zasób, który może być podstawą przewagi konkurencyjnej i długookresowych zysków. Dlatego niezależnie od kontekstu i sektora, kapitał marki powinien być diagnozowany, kreowany, monitorowany i mierzony".

Biorąc pod uwagę perspektywę zachowań konsumentów, kapitał marki jest rozumiany jako odpowiedź konsumentów na marketing marki ${ }^{36} \mathrm{i}$ jest szeroko stosowany w branżach komercyjnych jako indykator marki. Stąd wywodzi się, wprowadzony przez K.L. Kellera ${ }^{37}$, termin „,kapitał marki zorientowany na konsumenta/kapitał marki oparty na konsumencie" (ang. customer-based brand equity), który stawia w centrum skojarzenia i postawy potencjalnych oraz aktualnych użytkowników marki.

Kapitał marki zorientowany na konsumenta można ogólnie zdefiniować jako różnicujący efekt wiedzy o marce na reakcje konsumentów w odpowiedzi na marketing marki ${ }^{38} \mathrm{i}$ wskazać trzy istotne składowe takiego ujęcia: efekt różnicujący, wiedza o marce i odpowiedź konsumenta na marketing marki. Kapitał marki jest tym samym formułowany z perspektywy indywidualnego konsumenta.

D.A. Aaker identyfikuje wymiary kapitału marki jako: świadomość marki, skojarzenia z marka, postrzeganą jakość, lojalność wobec marki, a także pozostałe, dotyczące praw własności, takie jak: patenty, znaki towarowe i relacje w kanałach dystrybucji. Cztery pierwsze wymiary reprezentuja percepcje konsumentów i ich relacje z marka, podczas gdy aktywa marki dotyczące własności nie są związane z kapitałem marki bazującym na konsumencie. K.L. Keller patrzy na kapitał marki zorientowany na konsumenta wyłącznie z perspektywy psychologii - marka ma pozytywną (lub negatywna) wartość, jeśli konsument reaguje bardziej (lub mniej) przychylnie na marketing mix produktu, którego nazwę marki zna niż na marketing mix identycznego produktu, ale pozbawionego marki.

W literaturze przedmiotu za podstawowe źródła kapitału marki (w kontekście ogólnym) uważa się dwa wymiary: percepcyjny (mierzony za pomocą takich miar, jak: świadomość marki, skojarzenia z marka, wizerunek marki, postrzegana jakość itp.) oraz behawioralny (operacjonalizowany poprzez lojalność wobec marki, chęć zapłaty ceny premium, rekomendacje itd.).

Według K.L. Kellera kapitał marki zorientowany na konsumenta powinien opierać się na wysokim poziomie świadomości i znajomości marki oraz silnych, przychylnych i unikatowych skojarzeniach z marką. D.A. Aaker z kolei, jak już wspomniano, wskazuje

\footnotetext{
${ }^{35}$ D.A Aaker: Brand Leadership. The Free Press: New York, NY 2000, s.9.

${ }^{36}$ D.A Aaker: Building Strong Brands. The Free Press: New York, NY 1996; K.L. Keller: Conceptualizing, Measuring and Managing Customer-based Brand Equity. Journal of Marketing, vol. 57, no. 1, 1993.

37 K.L. Keller: Conceptualizing, Measuring and Managing Customer-based Brand Equity. Journal of Marketing, vol. 57, no. 1, 1993.

${ }^{38}$ W.A. Kamakura, G.J. Russell: Measuring Consumer Perceptions of Brand Quality with Scanner Data: Implications for Brand Equity, Report No. 91-122. Marketing Science Institute, Cambridge, MA, 1991; K.L. Keller: Conceptualizing, Measuring and Managing Customer-based Brand Equity. Journal of Marketing, vol. 57 , no. $1,1993$.
} 
świadomość marki, postrzeganą jakość, skojarzenia z marką oraz lojalność w stosunku do marki, które można uznać za właściwe podejście dla kapitału marki zorientowanego na konsumenta (rysunek 2).

Generalnie, pomimo różnic w terminologii i punktu ciężkości, obie konceptualizacje kapitału marki zaproponowane przez D.A Aakera i K.L. Kellera są podobne i jest to najczęściej adaptowane $\mathrm{w}$ literaturze przedmiotu i badaniach empirycznych ujęcie kapitału marki zorientowanego na konsumenta. Jednocześnie stanowią dobry punkt wyjścia do pomiaru tegoż kapitału.

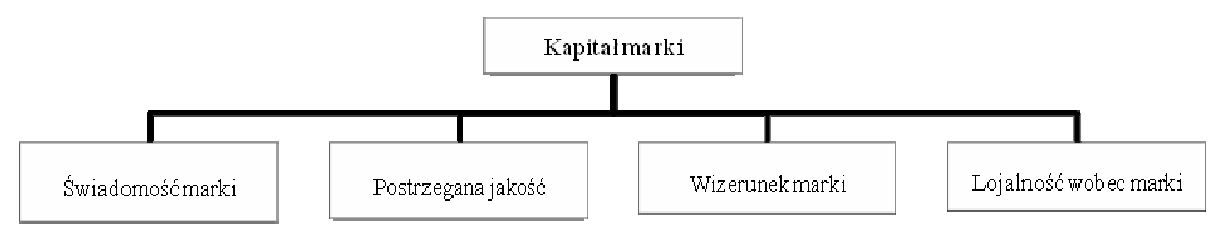

Rysunek 2. Źródła (wymiary) kapitału marki zorientowanego na konsumenta według Aakera Źródło: na podstawie: D.A. Aaker, Managing Brand Equity. Capitalizing on the Value of a Brand Name, The Free Press, New York 1991

Pomiar kapitału marki zorientowanego na nabywce jest przedmiotem częstych dyskusji akademickich ${ }^{39}$ oraz branżowych (np. Brand Asset Valuator, Young and Rubicam, Total Research Corporation's, Equitrend, Landor Associates, Image Power), w których wymiary kapitału marki są jednocześnie uznawane za poszczególne miary. I tak na przykład K.L. Keller i P. Lehmann sugerują, by pomiar kapitału marki zawęzić do pięciu wymiarów: świadomość marki, skojarzenia z markă postawy wobec marki, przywiązanie $\mathrm{i}$ aktywność. D.A. Aaker $\mathrm{w}$ zgodzie $\mathrm{z}$ sugerowanymi przez siebie wymiarami kapitału marki proponuje w tym względzie mierzyć: świadomość marki, skojarzenia z marka, postrzeganą jakość i lojalność, ale także dodatkowe miary związane z innymi aktywami niematerialnymi, takimi jak: patenty, znaki firmowe $\mathrm{i}$ relacje (bezpośrednio nie związane z konsumentem).

Odpowiadając na próby wiązania elementów finansowych $\mathrm{z}$ emocjonalnymi, R. Motameni i M. Shahrokhi ${ }^{40}$ proponują wycenę ,globalnego kapitału marki”, który składa się z kapitału z perspektywy marketingowej i kapitału z perspektywy finansowej. S. Davis ${ }^{41}$ porządkuje $\mathrm{z}$ kolei relacje między tymi dwoma ujęciami i uważa, że wartość marki (ang. brand value) powstaje z kapitału marki (ang. consumer-based brand equity). Podobnie jak P. Feldwick ${ }^{42}$ uważa, że kapitał marki jest pojęciem szerszym i nadrzędnym.

\footnotetext{
${ }^{39}$ np. D.A. Aaker: Managing Brand Equity. Capitalizing on the Value of a Brand Name. The Free Press, New York 1991; K.L. Keller: Conceptualizing, Measuring and Managing Customer-based Brand Equity. Journal of Marketing, vol. 57, no. 1, 1993.

${ }^{40}$ H.B. Kim, W.G. Kim, J.A. An: The Effect of Consumer-based Brand Equity on Firms' Financial Performance. Journal of Consumer Marketing, vol. 20, no. 4, 2003.

${ }^{41}$ S. Davis: A vision for the year 2000: brand asset management. Journal of Consumer Marketing, Vol. 12 No. 4, 1995.

${ }^{42}$ P. Feldwick: Defining a Brand, [w:] Cowley, D. (ed.): Understanding Brands. Kogan Page, London 1991.
} 
Autorzy kilku najnowszych studiów zaczęli poszukiwać powiązań pomiędzy kapitałem marki bazującym na konsumencie a wynikami rynkowymi. Badania te koncentrują się na związku między wskaźnikami marketingowymi i finansowymi, np. pomiędzy zadowoleniem klienta a rynkowymi wynikami firmy, a także pomiędzy oceną marki przez konsumentów a udziałem rynkowym firmy i penetracją rynku.

Równocześnie ze studiami akademickimi nad pomiarem kapitału marki, firmy konsultingowe i agencje badań rynkowych opracowują własne metodyki i podejścia, wykorzystywane niekiedy również $\mathrm{w}$ badaniach naukowych ${ }^{43}$. Najbardziej popularne zostały podsumowane w tabeli 3 .

Choć przedstawione podstawy teoretyczne kapitału marki nie dotyczą bezpośrednio marek terytorialnych, można przyjąć, że racjonalne uzasadnienie dla stosowania strategii marek i pomiaru jej kapitału jest takie samo niezależnie od sektora i rynku. Można zatem przypuszczać, że kapitał marki zorientowany na konsumenta ma również zastosowanie w odniesieniu do marek terytorialnych, dla których możliwe jest określenie odpowiedniego, związanego z kategorią marki terytorialnej, zestawu wymiarów i miar.

N. Papadopoulos i L. Heslop ${ }^{44}$ jako pierwsi uzasadnili stosowanie pojęcia kapitału marki miejsca z perspektywy inwestorów. Dokonali tego przenosząc ideę kapitału marki opartego o efekt kraju pochodzenia na kapitał marki kraju dla inwestorów (w ujęciu bezpośrednich inwestycji zagranicznych). Jednak najbardziej zbliżoną definicję istoty kapitału marki w kontekście terytorialnym zaproponował N. Papadopoulos ${ }^{45}$, który, opierając się na definicji kapitału marki D.A. Aakera ${ }^{46}$, określa kapitał marki terytorialnej (ang. place brand equity) jako „realne i/lub postrzegane aktywa i pasywa, które są kojarzone z miejscem i wyróżniają je spośród innych”.

\footnotetext{
${ }^{43}$ np. S. Chu, H.T, Keh: Brand Value Creation: Analysis of the Interbrand-Business Week Brand Value Rankings. Marketing Letters, vol. 17, no. 4, 2006; N. Mizik, R. Jacobson: The Financial Value Impact of Perceptual Brand Atributes. Journal of Marketing Research, vol. 45, no. 1, 2008.

${ }^{44}$ N. Papadopoulos, L. Heslop: Country Equity and Country Branding: Problems and Prospects. Journal of Brand Management, vol. 9, no. 4/5, 2002, ss. 294-314.

${ }^{45}$ N. Papadopoulos: Place Branding: Evolution, Meaning and Implications. Place Branding, vol. 1, no. 1, 2004, s. 36-49.

${ }^{46}$ D.A. Aaker: Managing Brand Equity. Capitalizing on the Value of a Brand Name. The Free Press, New York 1991, s. 43.
} 
Tabela 3. Pomiary kapitału marki prowadzone przez firmy doradcze

\begin{tabular}{|c|l|}
\hline $\begin{array}{c}\text { Agencja badawcza/nazwa narzędzia } \\
\text { badawczego }\end{array}$ & \multicolumn{1}{|c|}{ Miary kapitału marki } \\
\hline $\begin{array}{c}\text { Ynterbrand, Interbrand Brand Strength } \\
\text { BrandAsset Valuator }\end{array}$ & $\begin{array}{l}\text { rynek, stabilność, przywództwo marki, trend, poparcie } \\
\text { marki, dywersyfikacja, ochrona } \\
\text { wiedza, szacunek, zapotrzebowanie, odmienność }\end{array}$ \\
$\begin{array}{c}\text { Millward Brown International, } \\
\text { BrandDynamics }\end{array}$ & obecność, stosowność, działanie, przewaga, przywiązanie \\
Research International Equity Engine & $\begin{array}{l}\text { pokrewieństwo, postrzegane działanie funkcjonalne, } \\
\text { interakcja pomiędzy kapitałem marki a jej ceną } \\
\text { lojalność }\end{array}$ \\
NPD Group, Brand Builder & $\begin{array}{l}\text { unikalność , znajomość, popularność, istotność, związanie z } \\
\text { marką } \\
\text { przenikanie, indywidualność, jakość, stosunek jakości do } \\
\text { ceny, osobowość, potencjał, odporność rynkowa }\end{array}$ \\
Copernican Brand Equity Measurement and \\
Management System
\end{tabular}

Pierwszą pracą, która stricte dotyczyła kapitału marki terytorialnej, a także jej pomiaru było opracowanie M. Konecnik i W.C. Gartnera ${ }^{47}$, którzy opracowali model kapitału marki miejsca na przykładzie Słowenii. Opracowanie to dotyczy kapitału marki destynacji turystycznej (skierowanej do grupy docelowej potencjalnych i rzeczywistych turystów). M. Konecnik i W.C. Gartnera w swoich rozważaniach podążają za podejściem D.A. Aakera, włączając świadomość, wizerunek, jakość i lojalność jako odpowiednie wymiary dla kapitału marek destynacji, podkreślając jednak wagę wizerunku i jego funkcji w procesie kształtowania kapitału marki. Jest to zreszta popularne podejście w badaniach empirycznych, w których główny nacisk kładzie się na wizerunkowy element kapitału marki terytorialnej. Jednocześnie badania M. Konecnik i W.C. Gartnera sugerują, że wizerunek nie jest jedynym rozstrzygającym wymiarem w ocenie destynacji turystycznej ${ }^{48}$.

Inne prace związane z kapitałem marki terytorialnej także dotyczą przede wszystkim marek destynacji turystycznych. S. Boo i in. ${ }^{49}$ na przykład przetestowali model kapitału marki z perspektywy konsumenta za pomocą badania on-line na próbie odwiedzających Las Vegas i Atlantic City w Stanach Zjednoczonych. S.D. Pike i in. ${ }^{50}$ z kolei skupili się na turystyce długodystansowej (odległych podróży) na przykładzie Australii przy ocenie kapitału marki.

Część opracowań znajduje się pod wpływem menadżerskiego sposobu myślenia o marce - skupiają się głównie na kategoryzacji zasobów marki terytorialnej bez akcentu na ich ewaluację. W tej grupie, w kontekście miejskim, prezentowane są różnego

\footnotetext{
${ }^{47}$ M. Konecnik, W.C. Gartner: Customer-based Brand Equity for Destination, Annals of Tourism Research, vol. 34 , no. 2 , 2007, s. 400-421.

${ }^{48}$ Ibidem.

${ }^{49}$ S. Boo, J. Busser, S. Baloglu: A Model of Customer-based Brand Equity and Its Application to Multiple Destinations. Tourism Management, vol. 30, 2009.

${ }^{50}$ S. D. Pike: Consumer brand equity measures. „Journal of Travel and Tourism Marketing”, 22(1), 2007, ss.51-61.
} 
rodzaju modele, takie jak modele oceny marki miasta, modele marki miasta związane z formowaniem zasobów miejskich ${ }^{51}$ oraz modele wyjaśniające i ewaluacyjne głównych charakterystyk marek miejskich. W większości opierają się one na tradycyjnym podejściu do brandingu produktów, usług i budowania marek korporacyjnych.

Warto przy tym zwrócić uwagę na różnego rodzaju indeksy, wskaźniki i miary, które wykorzystywane są przez badaczy do określenia wpływu marki na miasto (tabela 4).

Tabela 4. Typy efektów marki miasta według obszarów i miar wpływu - przegląd opracowań

\begin{tabular}{|c|c|c|c|}
\hline & $\begin{array}{l}\text { Tożsamościowo- } \\
\text { wizerunkowy }\end{array}$ & Społeczno-polityczny & Gospodarczy \\
\hline $\begin{array}{l}\text { Wpływ } \\
\text { marki } \\
\text { miasta }\end{array}$ & 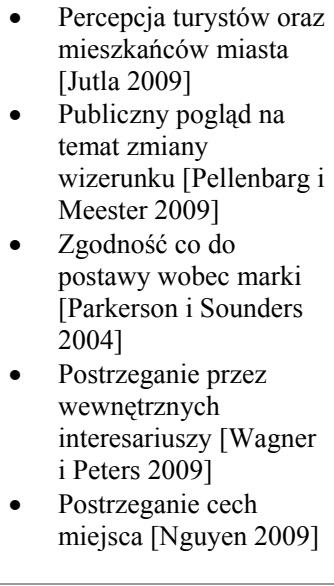 & $\begin{array}{ll}\text { - } & \text { Wpływ siły } \\
\text { interesariuszy na proces } \\
\text { brandingu [Marzano i } \\
\text { Scott 2009] } \\
\text { - Anty-kampania i } \\
\text { lokalne napięcia [Reid } \\
\text { 2007] } \\
\text { - Zakres konsultacji z } \\
\text { mieszkańcami } \\
\text { [Broudehoux 2007] } \\
\text { Imigracja i } \\
\text { międzyregionalne } \\
\text { przepływy ludności } \\
\text { [Niedomysl 2004] } \\
\text { Zaangażowanie lokalnej } \\
\text { społeczności [Jiwa i in. } \\
\text { 2009] }\end{array}$ & $\begin{array}{l}\text { Wydatki turystów i } \\
\text { zmiany w wartości } \\
\text { dodanej brutto/osobę } \\
\text { [Kozma 2009] } \\
\text { - } \text { Powroty turystów } \\
\text { oraz PKB [Plaza } \\
\text { 2008] } \\
\text { - Ceny czynszu oraz } \\
\text { nieruchomości } \\
\text { [Bagaeen 2009] } \\
\text { Produkcyjne miejsca } \\
\text { pracy/długość } \\
\text { funkcjonowania MSP } \\
\text { [Ruayan i } \\
\text { Huddelstone 2006] } \\
\text { Wzrost parytetu siły } \\
\text { nabywczej [Xuefei } \\
\text { 2008] }\end{array}$ \\
\hline
\end{tabular}

Źródło: A. Lucarelli, Unraveling the Complexity of "city brand equity": A Three-dimensional Framework,

Journal of Place Management and Development, vol. 5, iss. 3, 2012, s. 239.

Pierwszy obszar wpływu marki - „tożsamość-wizerunek” zawiera te, które mają bezpośredni wpływ i efekt na markę miasta jeśli chodzi o tożsamość miasta lub jego wizerunek. Autor celowo zamiennie używa terminów tożsamość i wizerunek ze względu na sposób ich stosowania przez badaczy $\mathrm{z}$ różnych dziedzin. Wpływ społecznopolityczny odnosi się do społecznych, politycznych i kulturowych rezultatów jako skutek oddziaływania marki miasta, podczas gdy wpływ gospodarczy dotyczy wyników bazujących na wskaźnikach ekonomicznych. Wpływ ten może być przy tym zarówno pozytywny, jak i negatywny.

Jak analizuje J.C. Belloso ${ }^{52}$ istnieje wiele różnego typu wskaźników, rankingów oraz klasyfikacji krajów, regionów i miast, które oceniaja pośrednio (w wielu obszarach) marki terytorialne. Sa to na przykład: wskaźniki konkurencyjności i rozwoju gospodarczego - The Global Competitiveness Index (CGI), jakości życia - Human Development Index (HDI), biznesu i inwestycji zagranicznych - Trust Index, turystyki Travel and Tourism Competitive Index (TTCI), korupcji - Corruption Perception Index

\footnotetext{
${ }^{51}$ np. L.A. Cai: Cooperative Branding for Rural Destinations. Annals of Tourism Research, vol. 29, no. 3, 2002.

52 J.C. Belloso: Evaluation of Existing Rankings and Assessment of the Country Brand. Paradigmes, iss. 5, 2010, s. 228-235.
} 
(CPI) itd. W przypadku miast, najczęściej przytaczane wskaźniki i prezentujące je raporty to: wskaźniki globalne - Global City Index Report, Global Power City Index, PricewaterhouseCooper Cities of Opportunity; z zakresu handlu i finansów - Global and World Cities Project, Global Financial Centres Index, MasterCard Centres of Commerce Index; kosztów życia - Mercer Cost of Living Report, Union Bank of Switzerland City Purchasing Parity, The Economist Worldwide Cost of Living; jakości życia-Mercer Quality of Living Report, The Economist Quality of Living i inne.

Biorąc pod uwagę perspektywę marketingowa, a jeszcze bardziej precyzyjnie marki, w literaturze odnaleźć można kilka opracowań, a na ich bazie kompleksowych indykatorów, które służą przede wszystkim zbudowaniu rankingów marek terytorialnych i w tym kontekście mają charakter głównie popularyzatorski. W większości przypadków dotyczą one skali marek narodowych (krajowych), choć opracowano też kilka metod pomiaru marek miejskich. Najbardziej znane indeksy odnoszące się do poziomu państw to: Anholt-GfK Roper Nation Brands Index (NBI) oraz The FutureBrand Country Brand Index (CBI).

Pierwszy, opracowany w 2005 roku przez konsultanta w dziedzinie reputacji państw Simona Anholta, ocenia wizerunek i reputację $e^{53}$ krajów oraz umożliwia analizę ich profili w sześciu wymiarach (inaczej: naturalnych kanałach komunikacji, działań i zachowań, które w sposób zamierzony lub nie budują reputację kraju). Są nimi: turystyka, marki eksportowe, polityka krajowa i zagraniczna, ludzie (obywatele kraju), inwestycje zagraniczne i napływ zasobów ludzkich, kultura i dziedzictwo ${ }^{54}$. Powyższe kanały komunikacji operacjonalizowane są w postaci pytań/stwierdzeń ocenianych w 7stopniowej skali Likerta. W badaniu stosuje się internetowe panele badawcze (w wykorzystaniem kwestionariusza).

Drugi ze wspomnianych rankingów, The Country Brand Index (CBI) opracowany przez agencję konsultingową FutureBrand, umożliwia ocenę i ranking krajów bazując na trzech elementach: globalnych badaniach ilościowych prowadzonych wśród turystów (osoby często podróżujące w celach biznesowych lub rekreacyjnych), opiniach oraz pogłębionych wywiadach $\mathrm{z}$ ekspertami, menedżerami i naukowcami, a także na analizach statystycznych. Ogólna ewaluacja poszczególnych krajów została skalkulowana na bazie autorskiego hierarchicznego modelu podejmowania decyzji (FutureBrand's Hierarchical Decision Model), na który składają się: świadomość, znajomość, skojarzenia, preferencja, rozpatrywanie, decyzja i popieranie marki ${ }^{55}$. Dzięki metodzie oceniane są jednak przede wszystkim skojarzenia z krajem w ramach: systemu wartości, jakości życia, oferty biznesowej, kultury i dziedzictwa oraz turystyki, a dodatkowo badane kraje klasyfikowane są według poziomu świadomości, znajomości, preferencji, rozpatrywania, faktycznej wizyty i rekomendacji kraju. Według autorów stosowany model umożliwia zarówno ocenę dojrzałości marki, jak i głównych wyzwań

\footnotetext{
${ }^{53} \mathrm{Z}$ punktu widzenia składowych kapitału marki wskaźnik ten bada zatem tylko jeden aspekt - wizerunku. ${ }^{54}$ Gfkamerica.com, The Anholt-GfK Roper City Brands Index, http://www.gfkamerica.com/practice_areas/roper_pam/placebranding/cbi/index.en.html 2012, [data dostępu: 03.07.2013].

${ }^{55}$ futurebrand.com, Future Brand, Country Brand Index, http://www.futurebrand.com/images/uploads/studies/cbi/2011-2012 FutureBrand CBI ENG.pdf [data dostępu: 12.07.2013].
} 
przed nią stojących. Metoda ta pozwala także ocenić działanie marki w porównaniu z innymi markami oraz jej postęp rok po roku.

W 2011 roku hiszpańska firma doradcza Bloom Consulting zaproponowała własny ranking krajów, $\mathrm{w}$ którym ocena $\mathrm{w}$ mniejszym stopniu wiąże się $\mathrm{z}$ aspektami percepcyjnymi i behawioralnymi. Ranking ten pod nazwą Ranking Marek Narodowych (ang. Bloom Consulting Country Brand Ranking) klasyfikuje państwa według kryterium skuteczności stosowanych przez nie strategii marek narodowych i wpływu, jakie wywierają one na PKB kraju. W celu sporządzenia tego rankingu Bloom Consulting bierze pod uwagę zmienne świadczące o wynikach gospodarczych państw (wszystkie dane pochodzą z uznanych źródeł, jak na przykład z Banku Światowego, Organizacji Narodów Zjednoczonych, Światowej Organizacji Turystycznej czy Światowego Stowarzyszenia Agencji Promocji Inwestycji) oraz zmienne charakteryzujące poprawność stosowanych strategii i ich akceptację na rynku.

Zgodnie z opracowaną przez siebie Metodą 3T (ang. 3T Approach), Bloom Consulting tworzy odrębne rankingi marek narodowych dla działalności gospodarczej (Trade) i turystyki (Tourism). Wyjaśniając istotę Metody 3T (przyciaganie działalności gospodarczej, turystyki i talentów, z jęz. angielskiego: trade, tourism, talent - 3T) autorzy wskazuja, iż w tradycyjnym podejściu stosowanym wobec wyzwania, jakim jest przyciagnięcie działalności gospodarczej, turystyki i talentów, tworzy się lub po prostu poprawia się postrzeganie kraju w ramach pojedynczej strategii ogólnej (tzw. strategii „parasola”), co według nich jest rozwiązaniem błędnym. Jak argumentują twórcy rankingu, nie można jednocześnie przekazywać inwestorom informacji o dostępnych rozrywkach, a turystom o wykwalifikowanej i pracowitej sile roboczej. To informacje z zupełnie różnych dziedzin, które powiązane osłabiają markę kraju, ponieważ w strategii ogólnej nie wykorzystują w pełni posiadanego potencjału. Ranking marek narodowych uzyskuje się w oparciu o: ocenę ratingową - ranking strategii marek narodowych (CBS Rating), dynamikę wzrostu gospodarczego oraz historyczną (przeszłą) efektywność gospodarki. Ranking nie wykorzystuje żadnych danych pochodzących $\mathrm{z}$ badań pierwotnych.

Ponieważ związek pomiędzy strategiami i efektywnością gospodarki nie jest natychmiastową relacją przyczynowo-skutkowa, Bloom Consulting bierze pod uwagę długoterminową (pięcioletnią) przeszłą efektywność gospodarki danego kraju w ramach bezpośrednich inwestycji zagranicznych (BIZ) - dla obszaru gospodarczego oraz wpływy z turystyki zagranicznej - dla rankingu w obszarze turystyki. Dzięki temu ranking ma odzwierciedlać trendy, a nie chwilowe zmiany mogące wystąić w warunkach poprawiającego się klimatu gospodarczego.

Podobny sposób analizy, jeśli chodzi o zestawienie potencjału marki terytorialnej z jej rzeczywistymi działaniami, przyjmuja, w kontekście miast, twórcy Europejskiego Barometru Marek Miast z londyńskiej agencji Saffron (Saffron's European City Brand Barometer $)^{56}$. Barometr mierzy silne strony marek miast i ocenia, na ile miasta używają marek do wykorzystywania swych aktywów. Okazuje się, że o ile marki niektórych miast osiagają wyniki poniżej oczekiwań w porównaniu ze swoimi aktywami, inne

\footnotetext{
${ }^{56}$ Opracowano na podstawie: J. Hildreth: The Saffron European City Brand Barometer. Revealing Which Cities Get the Brands They Deserve. Saffron Brand Consultants,

http://www.macrame.tv/storage/Saff_CityBrandBarom.pdf 2008, [data dostępu 1.07.2009].
} 
osiaggają więcej niż mogłyby sugerować ich zasoby. Analiza bierze pod uwagę zatem dwa aspekty: 1) Siłę atutów miasta (City asset strength, które odpowiada na pytanie: ,jak silna mogłaby być marka miasta, patrząc tylko na dające się zaobserwować i zmierzyć cechy miasta?") oraz 2) Siłę marki miasta (City brand strength, które odpowiada na pytanie: ,jak faktycznie silna jest marka miasta?”).

Jeśli chodzi o inne dostępne rankingi marek miast przygotowywane przez agencje doradcze, to warto zwrócić uwage na Anholt-GfK Roper City Brands Index ${ }^{\mathrm{TM}}$. Bazując na zaprezentowanym powyżej indeksie NBI, w 2006 roku opracowany został podobny indeks dla miast (obecnie pod nazwą Anholt-GfK Roper City Brands Index ${ }^{\mathrm{TM}^{57}}$ ), który mierzy wizerunek i reputacje 50 miast z krajów rozwiniętych i rozwijających się (głównie stolic i światowych aglomeracji). Indeks opracowywany jest poprzez uśrednienie wyników w sześciu kategoriach: obecność, miejsce, warunki podstawowe, ludzie, puls i potencjał, które tworzą tzw. Heksagon (sześciokąt) marki miasta ${ }^{58}$. Pod tymi wymiarami rozumie się:

1) Obecność/status (ang. presence) - ten wymiar dotyczy międzynarodowego statusu i pozycji miasta. Szczegółowe pytania składające się na ten wymiar dotyczą tego, w jakim stopniu respondenci znają każde $\mathrm{z}$ miast objętych badaniem i jaki każde $\mathrm{z}$ miast miało wkład w światową kulturę, naukę lub sposoby zarządzania w ciagu ostatnich 30 lat.

2) Miejsce (ang. place) - ten wymiar dotyczy postrzegania przez ludzi fizycznego aspektu miasta: czy przebywanie i podróż po mieście to przyjemność, czy też nie, jak interesujące jest miasto i jaki jest jego klimat.

3) Warunki (ang. prerequisities) - ten wymiar dotyczy podstawowych wymagań ludzi względem miast: jak łatwo, ich zdaniem, znaleźć zadowalające, niedrogie zakwaterowanie i jaki jest ogólny standard udogodnień publicznych - szkół, szpitali, transportu publicznego, obiektów sportowych itd.

4) Ludzie (ang. people) - ten wymiar dotyczy opinii i wyobrażeń na temat mieszkańców miasta: czy są oni serdeczni i przyjaźni, czy też zimni i uprzedzeni względem przybyszów z zewnątrz. Pytania dotyczą także tego, czy łatwo byłoby odnaleźć się i zaaklimatyzować w tej społeczności oraz bezpieczeństwa w mieście.

5) Puls/tętno życia miejskiego (ang. pulse) - ten wymiar dotyczy atrakcyjności miasta pod względem tętniącego życiem miejskim stylu życia. W tej części respondenci określają, jak łatwo można znaleźć w mieście interesujące zajęcia, będąc zarówno gościem chwilowym, jak i stałym rezydentem.

6) Potencjał (ang. potential) - ostatni wymiar heksagonu marki miasta bierze pod uwagę możliwości gospodarcze, jakie powinno oferować każde miasto. Uczestnicy badania pytani są, jak łatwo znaleźć pracę w mieście i czy gdyby mieli własną działalność gospodarczą jak dobrym miejscem, ich zdaniem, byłoby to miasto dla prowadzenia takiej działalności, czy każde z miast byłoby

\footnotetext{
57 Wcześniej przyjmował różne nazwy, w zależności od agencji badawczej zaangażowanej w jego przygotowanie.

${ }^{58}$ Gfkamerica.com, The Anholt-GfK Roper City Brands Index, http://www.gfkamerica.com/practice_areas/roper_pam/placebranding/cbi/index.en.html 2012, [data dostępu: 03.07.2013].
} 
odpowiednim miejscem dla nich lub członków ich rodzin do uzyskania kwalifikacji związanych z wyższym wykształceniem.

Heksagon miasta, który jest podstawą analiz i rankingu miast, jest szacowany na podstawie średniej wymiarów go tworzących, a zatem traktowane są w jednolity sposób, jeśli chodzi o wpływ na wynik końcowy. Dlatego wyniki ocen powinny być analizowane w ujęciu radarowym (na wykresie radarowym), by oddać rzeczywisty obraz sytuacji i siły marki miasta.

Zaprezentowane powyżej metody oceny marek terytorialnych bazują na zróżnicowanych przesłankach. $\mathrm{Z}$ jednej strony podstawą jest percepcja różnych zasobów miejsca (zarówno marek narodowych, jak i miejskich) (NBI). Z drugiej, bazą dla szacunków jest hierarchiczny model decyzji konsumentów, w ramach którego najsilniej eksponowane są skojarzenia z miejscem (aspekt wizerunkowy) (FutureBrand). Jako uzupełnienie klasyfikuje kraje według poziomu świadomości, znajomości, preferencji, rozpatrywania, faktycznej wizyty i rekomendacji kraju (CBI). Atuty marki postrzegane przez odbiorców są także zestawiane z siłą marki - najbardziej zbliżoną kategorią do kapitału marki (European City Brand Barometer). Ostatnie $\mathrm{z}$ analizowanych podejść (Bloom Consulting) polega na ocenie skuteczności działań związanych z marką. Oceniane są w tym przypadku mierzalne efekty realizowanej strategii marki, w tym sensie to podejście zbliżone jest do kapitału marki bazującego na przedsiębiorstwie.

Zaprezentowane metody korzystają z różnych podejść (D.A. Aakera, L.K. Kellera, modeli hierarchicznych), w niektórych przypadkach łącząc wybrane ich elementy. Stąd też poszczególne studia prezentują strukturę wymiarów kapitału marki terytorialnej $\mathrm{w}$ zróżnicowanych układach (co do ilości i składu wymiarów). Stanowią one przy tym bogaty zbiór elementów, które mogą stać się podstawą oszacowania skuteczności działań marketingowych $\mathrm{w}$ jednostkach terytorialnych.

\section{Zakończenie}

Metody pomiaru skuteczności wdrażania strategii marki terytorialnej zależą $\mathrm{w}$ dużym stopniu od sposobu interpretacji samego pojęcia „marka terytorialna”. W wąskim ujęciu, gdzie jest ona rozpatrywana przez pryzmat wyłącznie komunikacji marketingowej, znajdzie to swoje odzwierciedlenie we wskaźnikach skuteczności, które będą odnosiły się głównie do promocji. W szerokim i współczesnym rozumieniu natomiast, proces budowania marki terytorialnej traktuje się jako jedną z polityk publicznych i wówczas w przyjętych wskaźnikach oceny skuteczności odnosi się do szerokiego spektrum aktywności prowadzących np. do określonego kształtowania przestrzeni publicznej czy podnoszenia jakości życia mieszkańców. Projektując system pomiaru skuteczności strategii marki JST, podmioty publiczne powinny zatem rozpocząć od ustalenia czym jest marka miejsca, jakie funkcje pełni i jaki jest potencjalny zakres jej oddziaływania i projektowały wskaźniki skuteczności, które będą ich odzwierciedleniem.

Należy również zauważyć, że opisane w niniejszym opracowaniu metody pomiaru skuteczności strategii marki, pełnią różnorodne funkcje w procesie zarządzania marką terytorialną. Niektóre są bardziej użyteczne wewnętrznie (pozwalają organizacji monitorować własne działania i zależności wewnątrzorganizacyjne), inne zewnętrznie (stanowią pretekst do dalszego budowania reputacji wśród np. inwestorów, turystów czy opinii publicznej), jeszcze inne pełnią funkcję porównawczą (zestawiają osiagnięcia 
miast z jednostkami konkurencyjnymi). Są one również użyteczne w różnych obszarach funkcjonowania miast (gospodarce, turystyce, wzmacnianiu więzi społecznych etc.).

Tak jak ma to miejsce $\mathrm{w}$ przypadku pomiaru skuteczności działań związanych $\mathrm{z}$ budowaniem marek firm i produktów, w pomiarze skuteczności strategii marki terytorialnej, zdecydowanie należałoby stosować równolegle kilka wybranych metod pomiarowych, uwzględniających materialne i niematerialne (wizerunkowe, emocjonalne) rezultaty, wywodzące się nie tylko $\mathrm{z}$ marketingu, ale również $\mathrm{z}$ zarządzania publicznego. Pozwoli to na bardziej całościowe ujęcie oddziaływania marki na rzeczywistość danego miasta.

Warto jednak zauważyć, że jeśli miasto dąży do wypracowania jednolitego wskaźnika skuteczności strategii i kondycji marki, to za najbardziej trafny i uniwersalny należy uznać konstrukt kapitalu marki z perspektywy klienta. Pozwala on bowiem obserwować kondycję marki przez pryzmat potrzeb i percepcji głównych interesariuszy marki terytorialnej.

\section{Bibliografia}

Aaker D.A.: Managing Brand Equity. Capitalizing on the Value of a Brand Name, The Free Press, New York 1991

Aaker D.A: Brand Leadership, The Free Press: New York, NY 2000

Aaker D.A: Building Strong Brands, The Free Press: New York, NY 1996

Anders-Morawska J., Rudolf W.: Orientacja rynkowa we wspótrzq̨dzeniu miastem, Wydawnictwo Uniwersytetu Łódzkiego, Łódź 2015

Anholt S.: Competitive Identity: The New Brand Management for Nations, Cities and Regions, Palgrave Macmillan, New York 2007

Arnaboldi M., Lapsley I., Steccolini I.: Performance Management in the Public Sector: The Ultimate Challenge, Financial Accountability \& Management, 31(1), February,0267-4424, 2015

Belloso J.C.: Evaluation of Existing Rankings and Assessment of the Country Brand, Paradigmes, $5 / 2010$

Boo S., Busser J., Baloglu S.: A Model of Customer-based Brand Equity and Its Application to Multiple Destinations, Tourism Management, vol. 30, 2009

Bouckaert G., Halligan J.: Managing performance, International comparisons, Routledge, London 2008

Bouckaert G.: Conference paper, SSPA-SDA Bocconi Conference 2010, session: Public Sector Performance; managing Governments by numbers, http://sna.gov.it/www.sspa.it/wpcontent/uploads/2010/11/Bouckaert_Rome-2010.pdf, [data dostępu: 13.03.2017]

Cai L.A.: Cooperative Branding for Rural Destinations, Annals of Tourism Research, vol. 29, $3 / 2002$

Chaudhuri A.: Brand Equity or Double Jeopardy?, Journal of Product \& Brand Management, vol. $4,1 / 1995$

Chu S., Keh H.T.: Brand Value Creation: Analysis of the Interbrand-Business Week Brand Value Rankings, Marketing Letters, vol. 17, 4/2006

Davis S.: A vision for the year 2000: brand asset management, Journal of Consumer Marketing, Vol. 12, 4/1995

Feldwick P.: Defining a Brand, [w:] Cowley D. (ed.): Understanding Brands, Kogan Page, London 1991

Florek M.: Kapital marki miasta zorientowany na konsumenta - źródła i pomiar, Wydawnictwo Uniwersytetu Ekonomicznego w Poznaniu, Poznań 2014 
futurebrand.com, Future Brand, Country Brand Index,

http://www.futurebrand.com/images/uploads/studies/cbi/2011-2012_FutureBrand_CBI_ENG.pdf

[data dostępu: 12.07.2013]

Gfkamerica.com, The Anholt-GfK Roper City Brands Index,

http://www.gfkamerica.com/practice_areas/roper_pam/placebranding/cbi/index.en.html 2012,

[data dostepu: 03.07.2013]

Glińska E., M. Florek, Kowalewska A.: Wizerunek miasta - od koncepcji do wdrożenia, Wolters Kluwer Business, Warszawa 2009

Hanna S., Rowley J.: Towards a strategic place brand-management model, Journal of Marketing Management, Vol. 27 Nos 5/6, 2011

Hereźniak M.: Marka Narodowa. Jak skutecznie budować wizerunek i reputację kraju, PWE, Warszawa 2011

Hildreth J.: The Saffron European City Brand Barometer. Revealing Which Cities Get the Brands They Deserve, Saffron Brand Consultants, http://www.macrame.tv/storage/Saff_CityBrandBarom.pdf 2008, [data dostępu 1.07.2009]

Insch A.: Managing Residents' satisfaction with city life: application of importance satisfaction analysis, Journal of Town and City Management, 1(2)/2010

Kamakura W.A., Russell G.J.: Measuring Consumer Perceptions of Brand Quality with Scanner Data: Implications for Brand Equity, Report No. 91-122. Marketing Science Institute, Cambridge, 1991

Keller K.L.: Conceptualizing, Measuring and Managing Customer-based Brand Equity, Journal of Marketing, vol. 57, 1/1993

Kim H.B., Kim W.G., An J.A.: The Effect of Consumer-based Brand Equity on Firms' Financial Performance, Journal of Consumer Marketing, vol. 20, 4/2003

Kłeczek R.: Marketing $i$ wartość. Metodologiczne aspekty badania skuteczności $i$ działań marketingowych, Uniwersytet Ekonomiczny we Wrocławiu, Wrocław 2012

Konecnik M., Gartner W.C.: Customer-based Brand Equity for Destination, Annals of Tourism Research, vol. 34, 2/2007

Łapiński A.: Badania mediów dla celów reklamy, [w:] Komunikacja marketingowa, Rydel M. (red.), Ośrodek Doradztwa i Doskonalenia Kadr, Gdańsk 2001

Lin J., Lee P.: Performance Management in Public Organizations: A Complexity Perspective, International Public Management Review, Vol. 12, 2/2011

Lucarelli A., Unraveling the Complexity of "city brand equity": A Three-dimensional Framework, Journal of Place Management and Development, vol. 5, 3/2012

Malinowska M.: Efektywność i skuteczność komunikacji marketingowej, Difin, Warszawa 2015

Matwiejczuk R.: Zarzadzanie marketingowo-logistyczne. Wartość i efektywność, C.H. Beck, Warszawa 2006

Mizik N., Jacobson R.: The Financial Value Impact of Perceptual Brand Atributes, Journal of Marketing Research, vol. 45, 1/2008

Modzelewski P.: Kontrola zarzqdcza $w$ jednostkach sektora publicznego $w$ zakresie pomiaru skuteczności i efektywności, [w:] Sienkiewicz P., Świeboda H. (red.): Bezpieczeństwo, efektywność, budżet zadaniowy, AON, Warszawa 2014

Papadopoulos N., Heslop L.: Country Equity and Country Branding: Problems and Prospects, Journal of Brand Management, vol. 9, 4-5/2002

Papadopoulos N.: Place Branding: Evolution, Meaning and Implications, Place Branding, vol. 1, $1 / 2004$

Pike S. D.: Consumer brand equity measures, Journal of Travel and Tourism Marketing, 22(1)/2007

Pszczołowski J.: Mała encyklopedia prakseologii i teorii organizacji. Ossolineum, Wrocław 1978

Russo S., Frnetii F., Guthrie J., Marcon G.: Public Value Management: Measuring and Reporting, Emerald Group Publishing, Bingley 2014 
Rust R. T., Lemon K. N., Zeithaml V.A.: Return on marketing: Using customer equity to focus marketing strategy, Journal of Marketing, 2004

Sun B.: Public Management, Bestbooks Publisher New, Taipei 2009

Szołno O.: Wybrane aspekty pomiaru efektywności $i$ skuteczności jednostki samorzqdu terytorialnego. Finanse, Rynki Finansowe, Ubezpieczenia, 6/1 (84), 91-99. DOI: 10.18276/frfu.2016.84/1-08, 2016. s. 92

Szulce H., Żyminkowski T.: Znaczenie efektywności działań marketingowych $w$ ksztaltowaniu wartości przedsiębiorstwa, Wyd. Uniwersytetu Ekonomicznego w Poznaniu, Poznań 2010

Ustawa o finansach publicznych z dnia 27 sierpnia 2009, Dz.U. $2009 \mathrm{Nr} 157$ poz. 1240, art. 44 pkt. 3

Winters L.C.: Brand Equity Measures: Some Recent Advances, Marketing Research, vol. 3, 1991

Zenker S.: How to catch a city?, The concept and measurement of place brands, Journal of Place Management and Development, vol. 4, 1/2011

Zieleniewki J.: Organizacja i Zarzadzanie, PWN, Warszawa 1976

\section{Summary}

This paper attempts to present and systematize the diverse perspectives on effectiveness of branding activities in cities. The authors propose an approach to brand effectiveness measurement, drawing from both marketing and public management concepts and thus articulating implications for the practice of managing brands of cities.

The analysis of current approaches to the measurement of brand building activities that can be applied to cities was performed upon the concepts from marketing and public management. Theoretical assumptions of various measurement models were examined, serving as a basis for the critical analysis of effectiveness indicators resulting therefrom. Special attention has been given to the concept of place brand equity as a multidimensional measure of place brand effectiveness through the lenses of the place's key stakeholder groups.

It is proposed that the development of the measurement system for the effectiveness of place brand strategy should begin with the realization how public entities interpret the very notion of place brand, what functions does it perform and what is the scope of its influence on the place's reality. Such realization will have considerable impact on the effectiveness indicators that the public entities will consider indispensable for their brand strategies. Furthermore, the authors posit that to capture the multiple effects of brand strategy, the effectiveness indicators should encompass both tangible and intangible results of place branding and that it should not be limited to purely promotional indicators but rather include a wider set of measures referring to diverse timeframes.

Key words: place marketing, branding, cities' brand effectiveness measurement, brand equity

\section{Informacja o Autorach:}

\section{Dr Anna Augustyn}

Uniwersytet w Białymstoku, Zakład Ekonomiki i Finansów Samorządu Terytorialnego,

ul. Warszawska 63, 15-062 Białystok, a.auugustyn@uwb.edu.pl

\section{Dr Marta Hereźniak}

Uniwersytet Łódzki, ul. Narutowicza 59a, 90-131 Łódź, martaherezniak@uni.lodz.pl

Dr hab. Magdalena Florek

prof. UEP, Katedra Handlu i Marketingu Uniwersytet Ekonomiczny w Poznaniu, al. Niepodległości 10, 61-875 Poznań,m.florek@ue.poznan.pl 